been twice or three times up to the $100 \mathrm{ft}$. level or near, i.e. the 100 and $85 \mathrm{ft}$. rock ledges, covered with gravel of Acheulean date, and dirty sand at 100-110 feet after Clacton-Levallois timesBurkitt has proposed ponding of the North Sea to account for the latter.

(b) In regard to the second paper (p. 176), the coral island problem is a ticklish one for anyone not personally acquainted with the region to tackle. There is an impartial discussion by Steers (The Unstable Earth 1932) and the painstaking work of Chubb recently published (Geological Magazine, LXXI, 189). If for the reasons given above anything to do with a $1,000 \mathrm{~m}$. depression of ocean level is struck out as impossible, nothing much original is left.

(c) The third paper (p. 408) is a combination and amplification of the first two, and the geomorphology extremely speculative.

I must protest against Mr. Johns's description of his curve as a "Raised beach" curve. The only beaches he seems to know of are the 140,100 (these are grouped together. Why ?) and $25 \mathrm{ft}$. beaches. Fig. 2 loses interest when it is known that the so-called "Yoldia sea submergence" did not occur contemporaneously up the east coast of Britain.

However, mere criticism is tedious, and I am glad that there are points on which one can agree with Mr. Johns's findings. One is that the major glaciation of Scotland can be placed in the second half of Penck's Mindel-Riss interval, another that there has been subsidence (though I do not agree to recovery) in the north Pacific.

Might I suggest that Mr. Johns is attacking a very interesting problem in the wrong way, namely by forming a hypothesis and selecting facts to fit it? Surely the scientific method is to discover first what were the earth movements (wide variations in ocean level can no longer be entertained), taking as a starting-point the raised beaches and river terraces round Europe, second, what caused them?

R. G. LEWIS.

\title{
BLOCK FAULTING IN THE WESTERN RIFT OF CENTRAL AFRICA.
}

SIR,-In a letter published in the June issue of the Geological Magazine, Dr. E. O. Teale recorded observations by himself and Mr. G. M. Stockley to show that compression phenomena in the rocks along the margins of the Rift in Tanganyika Territory are very ancient and long antedate the present scarps, and that the Rift fractures are everywhere hest interpreted as associated with block movements. Mr. Stockley refers particularly to pre-Rift overthrusting in the Livingstone Mountains, and to block-faulting there and in the Ruhuhu trough; both these areas lie on the eastern side of Lake Nyasa. 
The object of this note is to record that the observations of the Nyasaland Geological Survey in and west of the Nyasan trough entirely confirm those of the Tanganyika Geological Survey on the eastern side. These observations may be summarized as follows :-

1. The Mafingi (Muva-Ankole) sediments north-west of Lake Nyasa show ample evidence of compression, and in the northern part of the Mafingi Mountains a magnificent overfold can be observed, in which the direction of movement is approximately parallel with the general direction of the neighbouring part of the Rift. But these movements were definitely pre-Karroo.

2. North-west of Lake Nyasa Karroo sediments lie west of, on the margin of, and within, the Rift; these sediments have been subject to early post-Karroo faulting and to Rift faulting, but in no case, except locally near the major post-Karroo faults, has any evidence of compression been observed, whereas there is ample evidence of block faulting. Farther south, in the Lake Chilwa region, pre-Karroo (? Waterberg) sediments lie undisturbed, apart from vertical movements, on the floor of the Rift.

3. North-west of Lake Nyasa, early Cretaceous, Tertiary, and Quaternary sediments also lie along the margin of, and within, the Rift; no evidence of compression has been observed, but all have been subject to block-faulting, and the older beds have been repeatedly tilted in the one direction, towards the deepest part of the Rift ; this hinge-faulting may be observed in parallel subsidiary rifts.

4. Where no sediments have been preserved, the crystalline rocks show step faults which vary from narrow shelves along the main walls to broad shallow steps that extend far out on to the floor of the Rift.

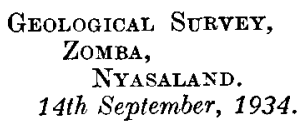

F. DIXEY, Direoror.

\section{UNIVERSITY OF LONDON.}

A course of three lectures on "Problems of the Archaean and Iron Ore Formations of Middle Sweden" will be given by Professor P. D. Quensel (Professor of Mineralogy and Petrography in the University of Stockholm) at The Imperial College-Royal School of Mines (Prince Consort Road, South Kensington, S.W. 7), on 19 th, 20th, and 22nd November, at 5.30 p.m. At the first lecture the Chair will be taken by Dr. H. H. Thomas, M.A., Sc.D., F.R.S., F.G.S. Admission Free, without Ticket. 